\title{
Analysis of Cell Lineage Relationships in Taste Buds
}

\author{
Leslie M. Stone, ${ }^{1,5}$ Seong-Seng Tan, ${ }^{3}$ Patrick P. L. Tam, ${ }^{4}$ and Thomas E. Finger ${ }^{2,5}$ \\ ${ }^{1}$ Department of Biomedical Sciences, Colorado State University, Fort Collins, Colorado 80523, ${ }^{2}$ Department of Cellular \\ and Structural Biology, University of Colorado Health Sciences Center, Denver, Colorado 80262, ${ }^{3}$ Brain Development \\ Laboratory, Howard Florey Institute, University of Melbourne, Parkville 3010, Australia, 'Embryology Unit, The Children's \\ Medical Research Institute, University of Sydney, Wentworthville, New South Wales 2145, Australia, and 5 Rocky Mountain \\ Taste and Smell Center, University of Colorado Health Sciences Center, Denver, Colorado 80262
}

Taste buds are a heterogeneous population of cells exhibiting diverse morphological and biochemical characteristics. Because taste buds arise from multiple progenitors, the different types of taste cells may represent distinct lineages. The present study was undertaken to determine the following: (1) how many progenitors contribute to a taste bud, and (2) whether the specific subpopulation of serotonin-immunoreactive (IR) taste cells are related by lineage to a restricted set of progenitor cells. These questions were addressed using cell lineage analysis of taste buds from $\mathrm{H} 253 \mathrm{X}$-inactivation mosaic mice. After random $X$-inactivation of the lac $Z$ transgene, the tongue of hemizygous female mice displays discrete patches of epithelial cells, which are either $\beta$-galactosidase ( $\beta$-gal) positive or $\beta$-gal negative. By analyzing the proportion of the two differently stained cell populations in taste buds located at the boundary between positive and negative epithelial patches, we can determine the minimum number of progenitors that may contribute to the formation of a taste bud. The presence of taste buds containing only $6-12 \%$ labeled cells indicates that at least eight progenitors contribute to an average taste bud of 55 cells, assuming progenitors contribute equally to the cell population. Cell lineage analysis of serotonin-IR taste cells in such mixed taste buds suggests that this subpopulation likely arises from only one to two progenitors and often is related by lineage. Thus, at least some of the cell types in a taste bud represent distinct lineages of cells and are not merely phenotypic stages as a cell progresses from a young to a mature state.

Key words: gustatory; development; basal cell; cell lineage; mosaic analysis; type III cell; serotonin
Taste buds, the sensory endorgans for the sense of taste, consist of $\sim 50-75$ spindle-shaped neuroepithelial cells (Finger and Simon, 2000). Taste bud cells are heterogeneous in terms of ultrastructure as well as immunocytochemical profiles (Lindemann, 1996; Finger and Simon, 2000). Based on ultrastructural characteristics, several different subclasses of intragemmal taste cells have been identified: basal cells, type I (dark) cells, type II (light) cells, and type III (intermediate) cells (Farbman, 1965a; Murray, 1969, 1973; Takeda, 1977; Takeda et al., 1981; Farbman et al., 1985; Kinnamon et al., 1985; Delay et al., 1986; Yee et al., 2001).

The significance of the different taste cell types, both in terms of function and cell lineage, is controversial. Like other epithelial cells, taste cells are continually replaced by a proliferative basal cell population (Beidler and Smallman, 1965; Conger and Wells, 1969; Farbman, 1980). Consequently, cells in each taste bud vary in age. Thus, phenotypic differences may reflect the life history of the cell in a taste bud. Conversely, phenotypic differences may reflect functional diversity. For example, some investigators sug-

\footnotetext{
Received Nov. 14, 2001; revised March 13, 2002; accepted March 18, 2002.

This work was supported by the National Institutes of Health (National Institute on Deafness and Other Communication Disorders Grant P01 DC00244) and the National Health and Medical Research Council (NHMRC) of Australia. P.P.L.T. is an NMHRC Senior Principal Research Fellow. We are grateful to John Caldwell, Joan Hooper, John Kinnamon, David Koeller, and Robert Lasher for critical discussions regarding this project. We also thank Karl Anderson, Bärbel Böttger, and Robin Michaels for technical assistance. Simvastatin was graciously supplied by Merck (Rahway, NJ). We especially appreciate Linda Barlow's comments on previous versions of this manuscript.

Correspondence to be addressed to Leslie M. Stone, Department of Biomedical Sciences, Colorado State University, Fort Collins, CO 80523. E-mail: 1stone@lamar. colostate.edu.

Copyright (C) 2002 Society for Neuroscience $\quad 0270-6474 / 02 / 224522-08 \$ 15.00 / 0$
}

gest that type III cells are the primary receptor cells of the taste bud, whereas type I cells play a supportive or glia-like role (Murray and Murray, 1971; Murray, 1986; Lindemann, 1996; Lawton et al., 2000). Two conflicting views exist in terms of cell lineage: (1) different taste cell types represent separate lineages that maintain a stable phenotype throughout the lifespan of the cells (Farbman, 1965a,b; Fujimoto and Murray, 1970, 1971, 1980; Pumplin et al., 1997), or (2) the taste cells change substantially with age, and the similarity in phenotype is associated with the acquisition of different functions by cells belonging to a common lineage (Delay et al., 1986). Even if separate lineages exist, some characteristics might appear only under certain conditions or states of maturation but could nonetheless be restricted to particular types of taste cells. For example, only some taste cells have the ability to accumulate serotonin, and these are all type III cells (Yee et al., 2001). However, not all type III cells accumulate serotonin. Whether this capability is related to lineage, functional status, or maturational state of the cell is unknown.

Previous analysis (Stone et al., 1995) of lineage complexity of $\mathrm{X}$-inactivation mosaic tongue tissues has shown that multiple progenitors give rise to individual taste buds. Thus, different cell lineages may exist within a single taste bud. The present study was undertaken to investigate whether a subpopulation of taste cells defined by the serotonin phenotype is a distinct sublineage arising from developmental mechanisms or alternatively consists of taste cells undergoing a serotonergic stage of their life cycle. This question was addressed using cell lineage analysis, which is able to retrospectively identify genealogical relationships among cells arising from common ancestry. 


\section{MATERIALS AND METHODS}

Mice. The mice used in these studies were $\mathrm{X}$-inactivation mosaic females hemizygous for an X-linked lacZ marker (Tam and Tan, 1992). This $\mathrm{H} 253$ line of mice carries $\sim 14$ tandem copies of an $8.9 \mathrm{~kb}$ fragment containing the promoter of the mouse housekeeping gene 3-hydroxy-3methylglutaryl coenzyme A (HMG-CoA) reductase, linked to the Escherichia coli lac $Z$ gene (Gautier et al., 1989). All studies reported herein were undertaken with the approval of the University of Colorado Institutional Animal Care and Use Committee and in accord with the guidelines of the Society for Neuroscience.

Because the transgenic marker is linked to the $\mathrm{X}$ chromosome, natural mosaics can be produced by mating male $\mathrm{H} 253$ mice to wild-type females. This mating results in female progeny that are hemizygous for the lac $Z$ marker, with the transgene present only on the paternally inherited $\mathrm{X}$ chromosome. During development of mammalian females, one of the two X chromosomes is randomly inactivated in each cell (Lyon, 1961). Inactivation in mouse ectodermal and mesodermal lineages is virtually completed by embryonic day 9.5 (E9.5) (Tan et al., 1993); therefore, all taste cells in the emerging tongue primordia at E11.5 (Paulson et al., 1985; Kaufman, 1992) would have a 50:50 composition, with one-half of the cells expressing the lac $Z$ gene product $\beta$-galactosidase ( $\beta$-gal).

Lingual tissue from transgenic male mice was used as a positive control for evaluation of $\beta$-gal expression in cells containing an active transgene. $\mathrm{X}$-Inactivation does not occur in males; thus, in $\mathrm{H} 253$ transgenic males, all cells should be $\beta$-gal positive $(\beta$-gal + ).

Simvastatin treatment. There is some variability in the expression of $\beta$-galactosidase in adult mouse tongue tissue (data not shown). To decrease this variability and to increase the production of $\beta$-galactosidase in cells retaining the active marker, Simvastatin was administered orally $(1 \mathrm{mg} / 100 \mathrm{ml}$ drinking water for 30-40 d) to both male transgenic mice and female mosaic mice. Simvastatin lowers cholesterol, a negative inhibitor of HMG-CoA reductase (Goldstein and Brown, 1990). Lower cholesterol, therefore, results in an increase in the production of HMG$\mathrm{CoA}$ reductase and in $\mathrm{H} 253$ mice, an increase in expression of the lac $Z$ gene driven by the $H M G-C o A$ reductase promoter.

Tissue preparation for analysis of lingual epithelium and taste buds from male H253 transgenic mice. Lingual tissue from male H253 mice was examined to determine the pattern of $\beta$-gal staining in transgenic male mice. Anesthetized mice ( $0.1 \mathrm{cc}$, i.p., $50 \mathrm{mg} / \mathrm{ml}$, Nembutal sodium solution; Abbott Laboratories, Chicago, IL) were perfused transcardially with $4 \%$ paraformaldehyde in $0.1 \mathrm{~m}$ phosphate buffer, and the tongues were removed. Fresh fixative was used to postfix lingual tissue for $45 \mathrm{~min}$, after which it was cryoprotected in $20 \%$ sucrose in $0.1 \mathrm{M}$ phosphate buffer overnight. The following morning, the tongue tissue was cryosectioned at 50-200 $\mu \mathrm{m}$ thickness. Resultant sections were washed three times, for 20 min each $(3 \times 20 \mathrm{~min})$, in washing buffer $\left(2 \mathrm{~mm} \mathrm{MgCl}_{2}, 5 \mathrm{~mm}\right.$ EGTA, $0.01 \% \mathrm{Na}$ desoxycholate, and $0.02 \%$ Nonidet $\mathrm{P}-40$ in $0.1 \mathrm{M}$ phosphate buffer) and then incubated overnight at $37^{\circ} \mathrm{C}$ in $\mathrm{X}$-gal solution: $0.1 \%$ 4-chloro-5-bromo-3-indolyl- $\beta$-D-galactopyranoside (X-gal) (Sigma, St, Louis, $\mathrm{MO}), 5 \mathrm{mM} \mathrm{K}_{3} \mathrm{Fe}(\mathrm{CN})_{6}$, and $5 \mathrm{mM} \mathrm{K}_{4} \mathrm{Fe}(\mathrm{CN})_{6} \cdot 6 \mathrm{H}_{2} \mathrm{O}$, in washing buffer. Stained sections were washed in $0.1 \mathrm{M}$ phosphate buffer $3 \times 10$ min, rinsed in distilled water for $10 \mathrm{~min}$, and dehydrated in graded ethanols, followed by acetone and put into infiltration solution (Historesin Plus basic resin with activator; catalog \#70-2224-861; Jung) overnight. The following morning, sections were placed into embedding solution (infiltration solution plus hardener) poured into molds.

Serial sections of 5-10 $\mu \mathrm{m}$ thickness were cut from polymerized plastic blocks after removal from the molds. These sections were counterstained with nuclear fast red, dehydrated through graded ethanols, cleared with Histoclear, coverslipped with Permount, and examined.

Numerical analysis of taste bud composition. To estimate the number of progenitors contributing to individual taste buds, $\beta$-gal + and $\beta$-galnegative $(\beta$-gal- $)$ cells were counted in individual taste buds containing few $\beta$-gal + cells. Hemizygous female transgenic mice were anesthetized and perfused by the same procedure described for male H253 mice. Postfixation of tongue tissue and cryoprotection also were identical to the procedures described for male mice. After cryoprotection, regions containing the circumvallate papillae, fungiform papillae, or palatal taste buds were cryosectioned at 50-70 $\mu \mathrm{m}$ thickness. Cryosectioning was done so that taste buds could be viewed longitudinally. Most counts were done using circumvallate taste buds because of the high concentration of taste buds in these papillae. Plastic sections of X-gal-stained material were produced as above for tissue from male tongues.

Image processing and analysis of mixed taste bud counts. Using both photomicrographs and mounted tissue sections, $\beta$-gal + (blue plus red) and $\beta$-gal - (red) intragemmal nuclei were counted in serial sections through entire taste buds. Inclusion of perigemmal cells in these counts was avoided because of the lack of $\beta$-gal activity in this cell population, even in nonmosaic mice (see Results, Lingual epithelium and taste buds from male $\mathrm{H} 253$ mice). Several features were used to distinguish between the nuclei of intragemmal taste cells and perigemmal or epithelial cell nuclei. Taste cell nuclei are more elongate and thinner than nuclei of surrounding epithelial cells; in general, taste cells and their nuclei are oriented approximately perpendicular to the surface of the crypt. In addition, in nuclear fast red counterstained sections, the cytoplasmic region of intragemmal taste cells was lighter than that of surrounding epithelial cells. This staining difference resulted in a distinct boundary around most taste buds. Although elongated and oriented similarly to taste cells, perigemmal cells contained less cytoplasm and were thinner than taste cells. These differences were obvious in central sections of taste buds in which the perigemmal cells were lateral to intragemmal cells. However, in the first and last sections of a taste bud, the distinction between intragemmal and perigemmal cells was less clear. Therefore, some perigemmal cells may have been included in the counts. The width of $\beta$-gal+ nuclei ranged in size from 2.5 to $7.5 \mu \mathrm{m}$ at their widest point $(n=9)$, and the width of $\beta$-gal- nuclei was similar, ranging in size from 2 to $8 \mu \mathrm{m}(n=67)$. Because the nuclei were similar in size, the sampling method used was unbiased. However, some nuclei may have been counted twice; serial sections were $5-10 \mu \mathrm{m}$ in thickness, resulting in larger nuclei being present in two sections.

Analysis of the number of taste bud progenitors. To provide a rough estimate of the minimal number of progenitor cells contributing to individual taste buds, the composition of mixed taste buds in the overall population was determined. These values can be compared with the proportions expected from a binomial distribution if two assumptions are made: (1) progenitors contribute equally to the taste bud population, and (2) different taste cells have approximately the same lifespan. If these assumptions are correct, then the proportions of $\beta$-gal-expressing and -nonexpressing cells in individual taste buds will resemble a binomial distribution. For example, if two progenitors contribute equally to a taste bud population, every mixed taste bud would be expected to contain $\sim 50 \% \beta$-gal + cells; three progenitors would result in mixed taste buds containing 33 or $66 \% \beta$-gal + cells, etc. The lowest percentage of $\beta$-gal + cells in mixed taste buds would be $50 \%$ if there were two progenitors but would be $33 \%$ if there were three progenitors (Fig. 1). Thus, the lower the contribution by $\beta$-gal + cells in a taste bud, the greater the predicted number of progenitors for that bud.

Eleven taste buds of the hundreds examined in the three mosaic mice exhibiting circumvallate mosaicism were selected for scoring because they contained both $\beta$-gal + and $\beta$-gal- cells, and they had a low number of $\beta$-gal + cells. Eight of the samples were from circumvallate papillae, two were from fungiform papillae, and one was from a palatal taste bud. In the fungiform and palatal samples, taste buds were more scattered and generally contained many $\beta$-gal + cells and therefore were not included in the present analysis. Initial analysis of the circumvallate taste buds revealed a wide variation in the number of $\beta$-gal + cells. Subsequent analysis was focused on those with few $\beta$-gal + cells. The number of taste buds containing few $\beta$-gal - cells in a mostly $\beta$-gal + taste bud was not determined because it is difficult to detect the few unstained cells amid a blue sea of $\beta$-gal + cells.

Serotonin cell lineage analysis. Taste cells recognized by anti-serotonin antibodies [5-HT immunoreactive (IR)] after pretreatment with the serotonin precursor 5-hydroxy-L-tryptophan (5-HTP) were chosen for initial taste cell lineage analysis because the relatively few (5-10) 5-HT-IR cells in mouse taste buds (Uchida, 1985; Fujimoto et al., 1987; Kim and Roper, 1995) facilitates statistical analysis.

Tissue preparation for 5-HT-IR cell lineage analysis. The cell lineage of 5-HT-IR taste cells was determined using mosaic analysis of taste buds double labeled with anti- $\beta$-galactosidase antibodies and anti-serotonin antibodies, followed by fluorescent-labeled secondary antibodies. Mice were treated with Simvastatin as described previously and then injected intraperitoneally with 5 -HTP $(80 \mathrm{mg} / \mathrm{kg}$ body weight; catalog \#3753; Sigma). One hour after 5-HTP injection, mice were anesthetized and perfused transcardially as above. In some cases, perfusion with fixative was preceded by $10-15 \mathrm{ml}$ of $0.9 \% \mathrm{NaCl}$ (Baxter, McGaw Park, IL). After perfusion, tongues were removed and placed in fresh fixative for 45-60 min. Postfixation was followed by cryoprotection in $20 \%$ sucrose in $0.1 \mathrm{M}$ phosphate buffer overnight. On the next day, 40-50 $\mu \mathrm{m}$ cryosections were collected in $0.1 \mathrm{M}$ PBS. 


\section{Progenitors}

\section{Progenitors}

Figure 1. The expected results of two or three progenitors giving rise to cells in a taste bud if the progenitors contribute equally to the cell population. Dark shading indicates $\beta$-gal + cells, and white indicates $\beta$-gal-cells.

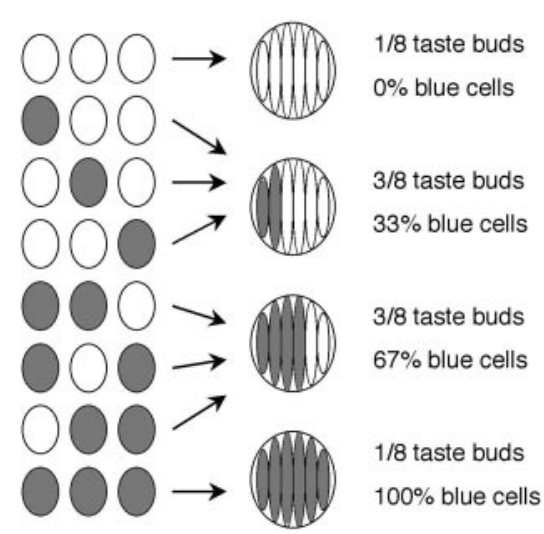

Immunocytochemistry. Two protocols were used for immunolabeling three sets of sections. The first set of sections was double labeled with anti- $\beta$-gal and anti-5-HT antisera. The second set of sections was triple labeled with $\beta$-gal antibodies, 5-HT antibodies, and 4'-6-diamidin-2phenylindol-dihydrochlorid (DAPI) (a fluorescent nuclear marker). A third set of sections was triple labeled with both antibodies and propidium iodide (a different nuclear marker). The first two sets of sections were treated as follows. Cryosections were washed in PBS $(3 \times 10 \mathrm{~min})$, placed into blocking solution [1\% bovine serum albumin (BSA), $1 \%$ normal horse serum, and $0.3 \%$ Triton X-100 in PBS] for 1-2 hr, and then incubated in a mixture of the polyclonal, primary antisera: goat antiserotonin (1:200 dilution; catalog \#108072; Incstar, Stillwater, MN) and rabbit anti- $\beta$-galactosidase (1:1000 dilution; catalog \#38952; Cappel, Cochranville, PA) in blocking solution. Taste cells labeled with the anti-serotonin antibodies are referred to as 5-HT-IR in this paper, although no attempt was made in this study to determine exactly the chemical nature of the substance recognized by the anti-serotonin antibody. Primary antibody incubation lasted for $36-48 \mathrm{hr}$, and then sections were washed in PBS $3 \times 10 \mathrm{~min}$ and incubated for $2-18 \mathrm{hr}$ in a mixture of secondary antibodies: FITC donkey anti-goat (1:100 dilution; catalog \#27384; Jackson ImmunoResearch, West Grove, PA) and Lissamine rhodamine donkey anti-rabbit (1:100 dilution; catalog \#27162; Jackson ImmunoResearch), followed by washes in PBS $3 \times 10 \mathrm{~min}$. The second set of sections was then incubated in DAPI $(0.33 \mathrm{gm} / \mathrm{ml}$; catalog \#12930720-31; Boehringer Mannheim, Indianapolis, IN) for 2 min and washed $3 \times 10 \mathrm{~min}$ in PBS. A third set of cryosections was triple labeled with anti- $\beta$-gal, anti-5-HT antisera, and propidium iodide. These were treated similarly to double-labeled and triple-labeled DAPI sections with the following exceptions: sections were incubated in PBS containing 2 $\mathrm{mg} / \mathrm{ml} \mathrm{BSA} \mathrm{(catalog} \mathrm{\# A-2153;} \mathrm{Sigma)} \mathrm{and} \mathrm{10 \%} \mathrm{donkey} \mathrm{serum} \mathrm{(DS)}$ (catalog \#017-000-121; Jackson ImmunoResearch) for 1-2 hr before primary antibody application, which consisted of PBS, BSA, DS, rabbit anti- $\beta$-gal (1:1000; catalog \#55976; Cappel), and goat anti-5-HT (1:200; catalog \#20079; DiaSorin, Stillwater, MN). Sections were left in primary antibody for $2 \mathrm{~d}$ at $4^{\circ} \mathrm{C}$, washed $3 \times 10 \mathrm{~min}$ in $\mathrm{PBS}$, and incubated overnight at $4^{\circ} \mathrm{C}$ in secondary antisera: FITC donkey anti-rabbit $(1: 100$; catalog \#711-095-152; Jackson ImmunoResearch) and Cy5 donkey antigoat (1:100; catalog \#705-175-147; Jackson ImmunoResearch). After secondary incubation, sections were washed $3 \times 10 \mathrm{~min}$ in PBS and placed into $0.1 \mathrm{M}$ PBS containing $10 \mathrm{mg} / \mathrm{ml} \mathrm{MgCl}_{2}$ and $250 \mu \mathrm{g} / \mathrm{ml}$ RNase A (Sigma) for $30 \mathrm{~min}$ at $35^{\circ} \mathrm{C}$. After washing again in PBS, tissue was placed in $0.5 \mu \mathrm{g} / \mathrm{ml}$ propidium iodide (Sigma) in $0.1 \mathrm{M}$ phosphate buffer for $1 \mathrm{~min}$, followed by $3 \times 10 \mathrm{~min}$ in PBS. Sections then were mounted on slides and coverslipped with Fluoromount G (Southern Biotechnology, Alabaster, AL). All experiments in each set included a negative control consisting of sections treated identically to the experimental sections except for a lack of primary antisera exposure. No inappropriate cross-reactivity by the secondary antisera was present in any of the sections.

Image processing and analysis. The circumvallate papillae of three mosaic mice were sectioned and double labeled with antibodies to $\beta$-gal and 5-HT, followed by the appropriate fluorescently tagged secondary antibodies. Taste buds with few $\beta$-gal-IR cells were chosen for analysis $(n=16$ buds) to increase the probability that the $\beta$-gal-IR cells were derived from a single, or few, progenitor cells. The 16 taste buds were analyzed by confocal microscopy. Two sets of confocal images were collected with a Bio-Rad (Hercules, CA) 600 laser scanning confocal microscope equipped with a helium-xenon laser and $\mathrm{K} 1$ and $\mathrm{K} 2$ filter blocks for simultaneous analysis of FITC and Lissamine rhodamine fluorescence. Two Z-series consisting of three to six images with 3-5 $\mu \mathrm{m}$ steps between images were collected for each taste bud. One Z-series was taken to detect 5-HT-IR and the other to detect $\beta$-gal-IR. The parameters for each Z-series of a pair were identical so that the $\beta$-gal-IR images and the 5-HT-IR images could be merged, with Photoshop software (Adobe Systems, San Jose, CA), into a series of double-labeled color images. The number of $\beta$-gal-IR nuclei, 5-HT-IR cells, and double-labeled ( $\beta$-gal-IR and 5-HT-IR) cells were counted for the portions of each taste bud contained within the Z-series. Because of a nuclear localization signal associated with the $\beta$-gal transgene, the $\beta$-gal-IR is nuclear, whereas 5-HT-IR is cytoplasmic. Accordingly, it was easier to locate and identify 5-HT-IR taste cells because of the larger volume occupied by immunoreactive cytoplasm compared with the nucleus. Thus, to avoid biased sampling, 5-HT-IR cells were counted only if the nucleus was visible. In addition, eight of the taste buds were counterstained with the nuclear stain DAPI and examined with a Zeiss (Oberkochen, Germany) standard microscope equipped for epifluorescence. Lissamine-rhodamine ( $\beta$-gal-IR nuclei), fluorescein (5-HT-IR cells), and DAPI (all nuclei) labeling were viewed and photographed separately. The resulting color slides were digitally scanned, and the images were combined using Photoshop software to produce tri-color images. Both images and microscopic viewing were used to count the number of DAPI-labeled nuclei, $\beta$-gal-IR nuclei, and 5-HT-IR cells in sections through taste buds.

Circumvallate and foliate papillae were collected from five additional mice, sectioned, and triple labeled with antibodies to $\beta$-gal and 5-HT, followed by their appropriate secondary antibodies and then propidium iodide. These sections also were analyzed by confocal microscopy. Two sets of confocal images were collected for each selected region, one to detect $\beta$-gal (FITC secondary antibody) and propidium iodide (red fluorescent) labeling and one to detect 5-HT-IR (Cy5 secondary antibody). Each set consisted of a series of images collected 3-5 $\mu \mathrm{m}$ apart, and the parameters for each set of a pair were identical as described for $\beta$-gal, 5-HT-IR double-labeled sections. Thus, triple-labeled images were obtained by merging two images collected in a single focal plane using Photoshop software. Merged images of single confocal sections were used to count $\beta$-gal-IR cells, 5-HT-IR cells, double-labeled cells, and nuclei (stained with propidium iodide) in selected taste buds $(n=16)$.

Taste buds from all three sets of sections (double labeled and triple labeled with DAPI or propidium iodide; $n=32$ total buds) were used to determine whether the 5-HT-IR cells in individual taste buds arise from one or multiple progenitors. Sections triple labeled with both antibodies and propidium iodide $(n=16)$ were used to study the cell lineage of 5-HT-IR cells.

Statistical analysis. Counts of labeled nuclei obtained from tri-color images were used to test whether 5-HT-IR taste cells are related by lineage. The final numerical analysis was done using sections labeled with both antisera and propidium iodide because all three labels were identifiable with confocal microscopy $(n=16$; see Table 2$)$. The null hypothesis tested was that the presence of $\beta$-gal-IR and 5-HT-IR are independent events. For this analysis, the expected distribution of propidium iodide-labeled nuclei, 


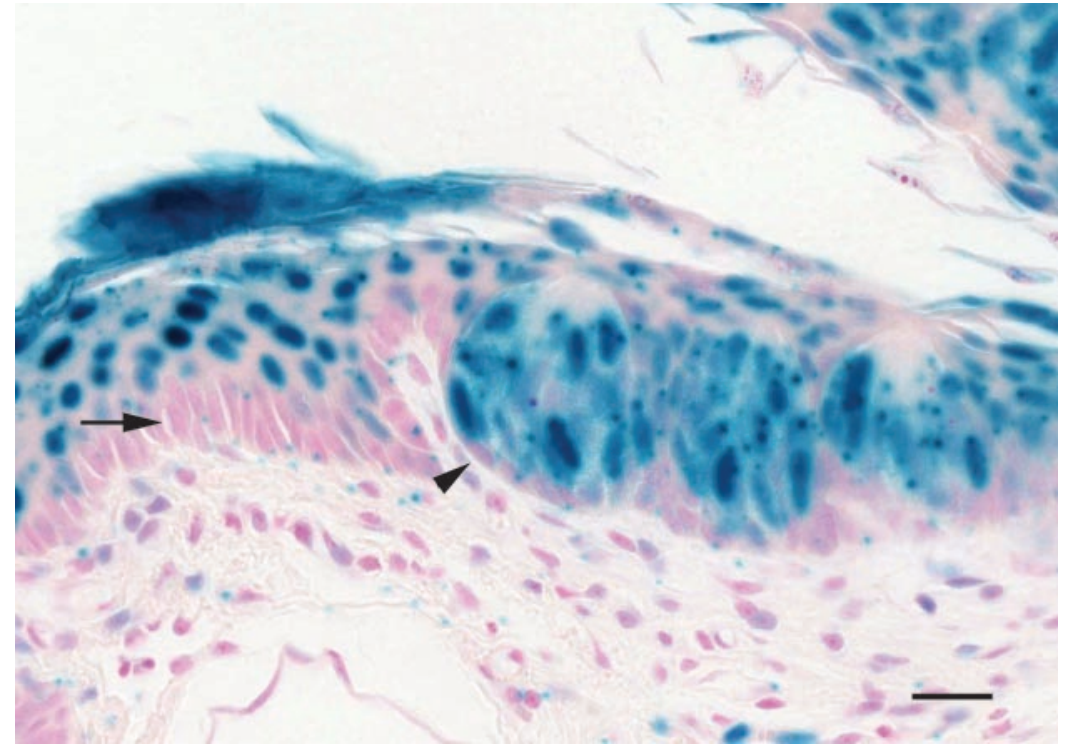

Figure 2. Light microscopic image of lingual tissue from an adult male H253 mouse treated with Simvistatin. Tissue was sectioned, stained with X-gal, and then counterstained with nuclear fast red. Blue, nuclear precipitate indicates $\beta$-gal activity. Basal cells in nontaste bud-bearing epithelium lack $\mathrm{X}$-gal staining (arrow), as do perigemmal cells surrounding the taste bud (arrowhead). Scale bar, $20 \mu \mathrm{m}$.

Table 1. Distribution of the percentage of $\beta$-gal+ cells in eight circumvallate taste buds

\begin{tabular}{llllllllll}
\hline$\% \beta$-gal+ cells & 6 & 7 & 8 & 9 & 10 & 11 & 12 & 13 & 14 \\
$\beta$-gal+/N & $4 / 66$ & & $4 / 48$ & & $6 / 59$ & & $6 / 49$ & $4 / 30$ & 15 \\
& & & & & $4 / 40$ & & $10 / 82$ & $11 / 62$ \\
\# Taste buds & 1 & 0 & 1 & 0 & 2 & 0 & 2 & 1 & 0 \\
\hline
\end{tabular}

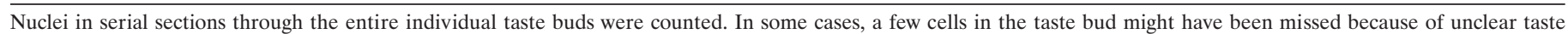
bud boundaries. Counts did not include perigemmal cells. $\beta$-gal $+/ N$, Actual count of $\beta$-gal+ cells per total number of cells in that taste bud.

5-HT-IR cells with nuclei, $\beta$-gal-IR nuclei, and double-labeled nuclei (5-HT-IR and $\beta$-gal-IR) was compared by $\chi^{2}$ analysis with the actual distribution of labeled nuclei. To determine the expected distribution of independently labeled nuclei, the following calculations were made: $D_{\mathrm{p}}=$ $p_{\mathrm{D}} X^{*} N$, where $D_{\mathrm{p}}$ is the expected number of double-labeled cells in a taste bud, $p_{\mathrm{D}}$ is the probability of double-labeled cells in that taste bud, and $N$ is the total number of cells sampled, assuming independent events; $p_{\mathrm{D}}=p_{\beta} X$ ${ }^{*} p_{\mathrm{s}}$, where $p_{\beta}$ is the probability of $\beta$-gal + cells in a taste bud, and $p_{\mathrm{s}}$ is the probability of 5-HT-IR cells; and $p_{\beta}=n_{\beta} / N p_{\mathrm{s}}=n_{\mathrm{s}} / N$, where $n_{\beta}$ is the total number of $\beta$-gal+ cells in a taste bud, and $n_{\mathrm{s}}$ is the total number of 5 -HT-IR cells in that taste bud.

The above values were determined for a series of sections through each taste bud using actual counts of the total number of $\beta$-gal-IR cells, the total number of 5-HT-IR cells, and the total number of propidium iodide-labeled cells in serial confocal images through sections of taste buds. Values for the probability of single-labeled cells were calculated by subtracting the expected number of double-labeled cells from the total number of either 5-HT-IR cells or $\beta$-gal-IR cells. The calculated values for 5-HT-IR only cells, $\beta$-gal-IR only cells, and double-labeled cells were then compared by $\chi^{2}$ analysis, with the actual counts shown in Table 2.

\section{RESULTS}

\section{Lingual epithelium and taste buds from male H253 mice}

To ensure that the relevant cells constitutively express reductasedriven lacZ, we examined the lingual epithelium of male transgenic mice treated with Simvistatin. Although not all cells in the adult male transgenic mice expressed $\beta$-gal, the tongue tissue displayed uniform $\beta$-gal activity in all cells of the cornified, granular, and spinous layers of the lingual epithelium (Fig. 2). In contrast, the basal layer showed little or no $\beta$-gal activity. All of the intragemmal cells of the taste bud strongly expressed $\beta$-gal but not the perigemmal cells surrounding the taste bud (Fig. 2).

\section{Proportions of $\boldsymbol{\beta}$-gal+ cells in mixed taste buds}

For lineage analysis, only taste buds with few (2-18) $\beta$-gal+ cells were used. The presence of few $\beta$-gal + cells in a taste bud increases the probability that the $\beta$-gal + cells arise from the same progenitor. Cell lineage questions were addressed by using immunocytochemistry to identify taste cells labeled by 5 -HT antibodies (5-HT-IR), $\beta$-gal antibodies, or both and then analyzing the relationship between 5-HT immunoreactivity and $\beta$-gal immunoreactivity. If 5-HT-IR cells arise from a single progenitor, either all cells would be double labeled (with 5-HT-IR and $\beta$-gal-IR) or all single labeled (5-HT-IR only). In contrast, if a taste bud contains both 5-HT-IR, $\beta$-gal-IR double-labeled cells and single-labeled 5-HT-IR cells, then 5-HT-IR cells arise from multiple progenitors, because $\beta$-gal + and $\beta$-gal - cells must have arisen from different progenitors. A correlation analysis of the relative incidence of $\beta$-gal-IR and 5-HT-IR cells was performed to test whether 5-HT-IR cells are related by lineage (see Materials and Methods, Statistical Analysis).

Many taste buds of female hemizygous transgenic mice were found to contain fewer than $50 \% \beta$-gal + cells. The lowest contribution of $\beta$-gal+ cells in a circumvallate taste bud was $6 \%$, although more commonly, $8-13 \% \beta$-gal + cells was found (Table 1, Fig. 3). In a taste bud that contains an average of 55 cells, $8-13 \%$ implies the presence of four to seven labeled cells. If every progenitor in the taste bud gives rise to equal numbers of progeny cells, one labeled cell in a pool of 14 progenitors will produce a taste bud containing four labeled cells ( $8 \%$ of the total population). By a similar argument, one labeled cell in a pool of eight 
Figure 3. Light microscopic images of $5 \mu \mathrm{m}$ serial sections through circumvallate taste buds from an $\mathrm{H} 253$ mosaic mouse. The adult female mouse was treated with Simvistatin, and the tissue section was stained with $\mathrm{X}$-gal solution as described in Materials and Methods, embedded in Historesin, resectioned, and stained with nuclear fast red. Asterisks indicate a taste bud with few $\beta$-gal + cells (blue). Scale bar, $20 \mu \mathrm{m}$.

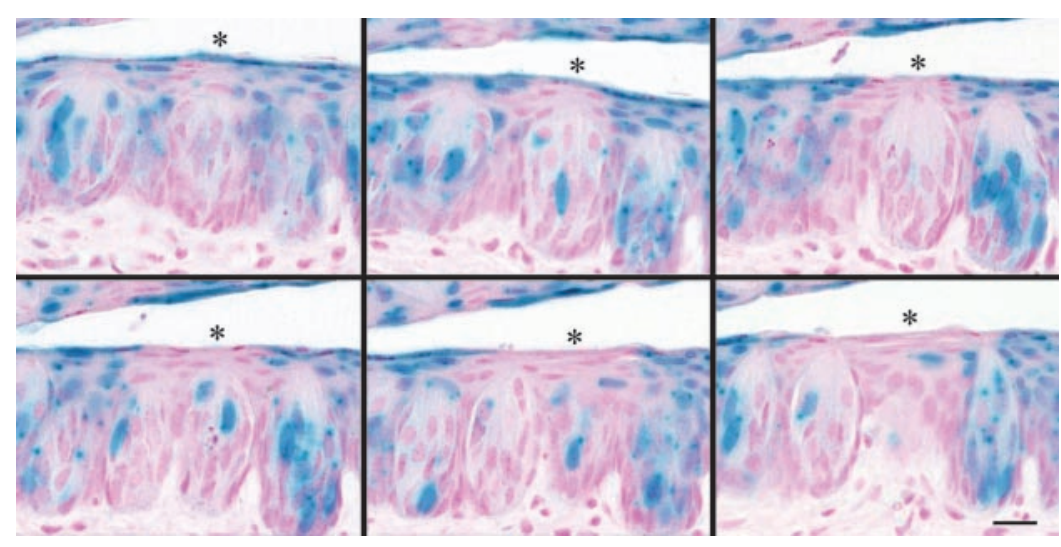

\begin{tabular}{|c|c|c|c|c|c|c|c|}
\hline & $\begin{array}{l}\text { Total number } \\
\text { cells }(N)\end{array}$ & $\begin{array}{l}\text { Total } \beta \text {-gal-IR } \\
\text { cells }\end{array}$ & $\begin{array}{l}\beta \text {-gal-IR } \\
\text { only cells }\end{array}$ & $\begin{array}{l}\text { Double- } \\
\text { labeled cells }\end{array}$ & $\begin{array}{l}\text { 5-HT-IR } \\
\text { only cells }\end{array}$ & $\begin{array}{l}\text { Total 5-HT-IR } \\
\text { cells }\end{array}$ & $p$ value \\
\hline TB 1 & 11 & 4 & 0 & 4 & 0 & 4 & 0.01 \\
\hline TB 2 & 9 & 6 & 3 & 3 & 0 & 3 & 0.52 \\
\hline TB 3 & 8 & 3 & 3 & 0 & 2 & 2 & 0.66 \\
\hline TB 4 & 10 & 4 & 3 & 1 & 1 & 2 & 0.99 \\
\hline TB 5 & 13 & 3 & 1 & 2 & 1 & 3 & 0.24 \\
\hline ТВ 6 & 8 & 5 & 0 & 5 & 0 & 5 & 0.05 \\
\hline TВ 7 & 15 & 2 & 0 & 2 & 1 & 3 & 0.03 \\
\hline TB 8 & 16 & 3 & 3 & 0 & 3 & 3 & 0.84 \\
\hline TB 9 & 16 & 2 & 1 & 1 & 2 & 3 & 0.70 \\
\hline TB 10 & 16 & 5 & 3 & 2 & 0 & 2 & 0.17 \\
\hline TB 11 & 20 & 7 & 2 & 5 & 0 & 5 & 0.006 \\
\hline TB 12 & 14 & 5 & 3 & 2 & 0 & 2 & 0.24 \\
\hline TB 13 & 17 & 6 & 2 & 4 & 0 & 4 & 0.02 \\
\hline TВ 14 & 24 & 12 & 6 & 6 & 1 & 7 & 0.17 \\
\hline TB 15 & 11 & 5 & 2 & 3 & 0 & 3 & 0.17 \\
\hline TB 16 & 10 & 4 & 3 & 1 & 1 & 2 & 0.99 \\
\hline
\end{tabular}

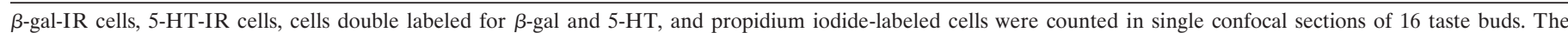

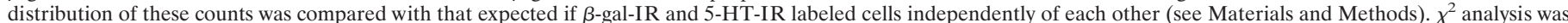

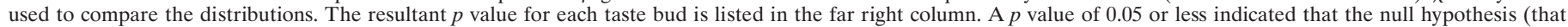

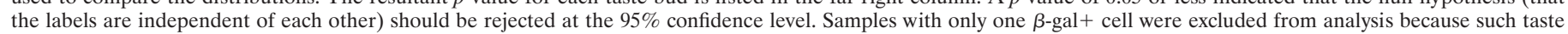
buds provide no information about lineage. $N$ was obtained by counting nuclei stained with propidium iodide in a specified region. TB, Taste bud.

progenitors would produce a taste bud exhibiting seven labeled cells $(13 \%$ of total population).

In addition to the circumvallate taste buds, two fungiform taste buds were analyzed. The lowest contribution of $\beta$-gal+ cells in the two fungiform taste buds was $31 \%$, suggesting that at least two progenitor cells may be required to populate the whole taste bud (data not shown). However, because only two samples were analyzed, no definitive statement on the size of progenitor pool may be made for the fungiform taste bud.

\section{Cell lineage analysis of taste cells labeled with serotonin antibodies}

To resolve the issue of whether different morphological or histochemical types of taste cells represent independent cell lineages or instead a particular developmental stage of a single taste cell lineage, we examined the relationship between 5-HT-IR taste cells [a phenotypic subpopulation of type III cells (Yee et al., 2001)] and $\beta$-gal-IR nuclei in H253 transgenic, mosaic mice. Thirty-two taste buds were analyzed (from sections double labeled with both antibodies and from triple-labeled DAPI and triple-labeled propidium iodide sections), and the outcome was grouped under three categories: 5-HT-IR and $\beta$-gal-IR, 5-HT-IR only, and $\beta$-gal-IR only.

Both 5-HT-IR only cells and 5-HT-IR/ $\beta$-gal-IR double-labeled cells were present in the majority of taste buds studied (Table 2 shows results from triple-labeled propidium iodide sections; Fig. 4). The presence of both 5-HT-IR only cells and double-labeled cells in the same taste bud indicates that more than one progenitor gave rise to the 5-HT-IR cells in that taste bud because $\beta$-gal + cells and $\beta$-gal - cells cannot arise from the same progenitor. Furthermore, based on the binomial distribution, because approximately one-half of the taste buds contain both 5-HT-IR only cells and double-labeled cells (15 of 32), it is likely that two progenitors contribute to the 5-HT-IR cells in individual taste buds. However, the number of taste buds with only doublelabeled cells $(n=12)$ is approximately twice the number expected on the basis of binomial statistics with two progenitors $(n=15)$. This suggests that, in some taste buds, only one progenitor gave rise to the entire 5-HT-IR subpopulation.

Sections triple labeled for 5-HT-IR, $\beta$-gal, and propidium iodide (Fig. 4) were analyzed in more detail to determine whether 


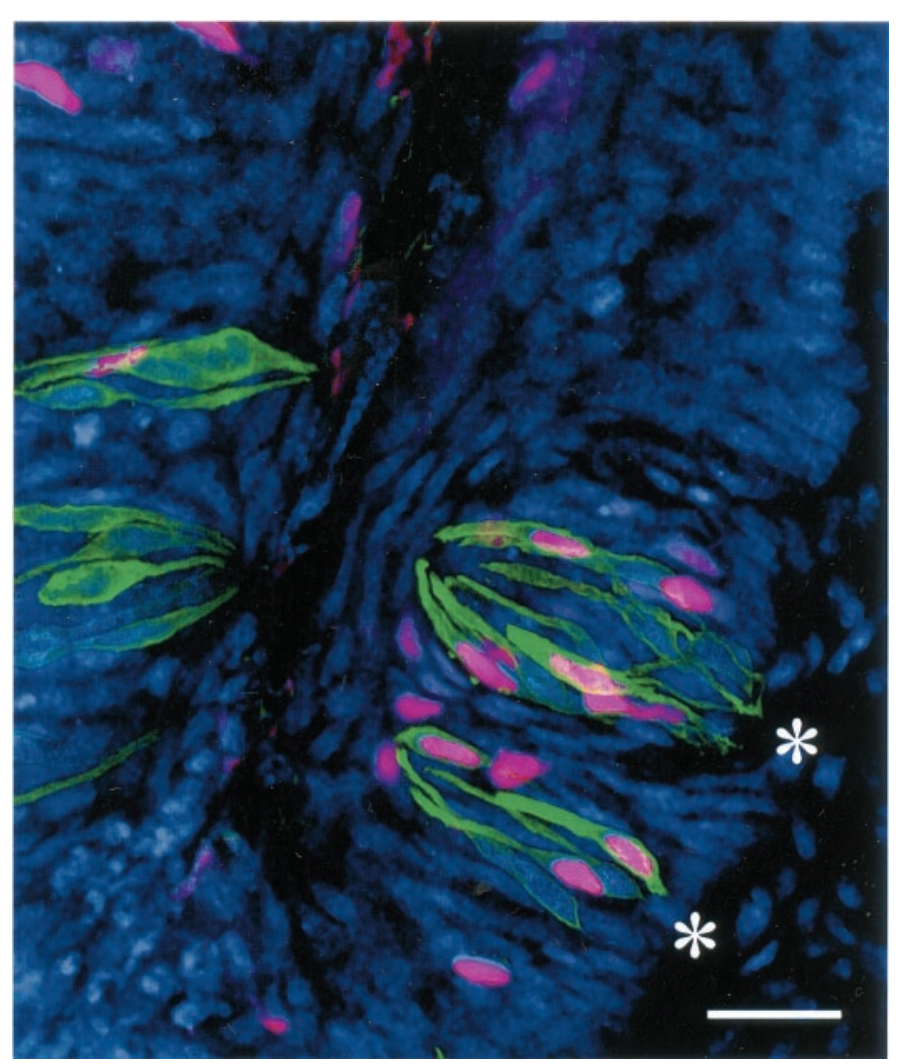

Figure 4. Confocal image of circumvallate taste buds from an $\mathrm{H} 253$ mosaic mouse, triple labeled for $\beta$-gal-IR ( magenta), 5-HT-IR (green), and propidium iodide (blue). This figure was obtained by merging two confocal images using Photoshop software as described in Materials and Methods. The Photoshop filter "dust and scratches" was used to remove artifactual speckles from the merged image (pixel value was 3 ). Note that both 5-HT-IR only cells (green) and double-labeled cells (green and magenta) are present in individual taste buds (e.g., bud indicated by asterisk). This indicates that more than one progenitor gave rise to the 5-HT-IR cells in those buds. Scale bar, $20 \mu \mathrm{m}$.

there was a lineage relationship between 5-HT-IR taste cells. Counts from 16 taste buds are presented in Table 2. The idea that 5-HT-IR taste cells are related by lineage is supported by $\chi^{2}$ analysis of the actual and expected distributions of 5-HT-IR, $\beta$-gal-IR, and propidium iodide-labeled nuclei. In five of the 16 taste buds (Table 2), the distribution of $\beta$-gal-IR cells, 5-HT-IR cells, double-labeled cells, and nonimmunoreactive cells differed significantly from the distribution expected if $\beta$-gal antibodies and 5-HT antibodies labeled taste cells independently $(p<0.001)$ (Table 2). Thus, 5-HT-IR cells within a taste bud show lineage relationships and are more likely to share a common progenitor with each other than with non-5-HT-IR cells in a taste bud.

\section{DISCUSSION}

The key conclusions of this study are as follows: (1) at least eight progenitor cells contribute to each circumvallate taste bud, based on the assumption that all progenitor cells make equal contribution, and (2) amine-accumulating (5-HT-IR) cells in a taste bud are likely to be clonal descendants of a subset of progenitors. Thus, the different cell types in a mature taste bud are not merely phenotypic, temporal stages of a common taste cell type but likely represent distinct cell lineages that are independent of one another once they have undergone terminal division from the basal cell population. Furthermore, these findings indicate that at least some of the proliferative cells contributing to a taste bud have a limited repertoire of progeny, i.e., particular basal cells may generate only one or two of the three cell types in a taste bud.

\section{Analysis of taste bud progenitor number}

Individual taste buds arise from several progenitors. In circumvallate taste buds from mosaic mice, $8-13 \%$ of taste cells are $\beta$-gal + in taste buds with the fewest $\beta$-gal + cells. From our counts, $\sim 55$ intragemmal cells are present in an average mouse circumvallate taste bud. Eight to $13 \%$ translate into approximately four to eight $\beta$-gal+ cells in an average taste bud consisting of 55 cells. If progenitors contribute equally, these proportions would result from a relatively large progenitor pool, e.g., eight total progenitors consisting of seven $\beta$-gal - and one $\beta$-gal + cell [producing seven cells each, for a total of 56 cells, with seven $(12.5 \%)$ being $\beta$-gal+]. This fairly large number of progenitors per taste bud correlates reasonably well with the number of cells present in early taste bud placodes that give rise to fungiform papillae and their taste buds. These placodal cells represent, or contain, the progenitor pool for incipient taste buds (Farbman and Mbiene, 1991). In E14 mice, at the earliest stages of molecular differentiation of the incipient taste bud, the fungiform taste placodes consist of $\sim 10-12$ cells exhibiting sonic hedgehog mRNA (Hall et al., 1999).

However, the architecture of $\beta$-gal + patches in the lingual epithelium suggests that a single $\beta$-gal + progenitor would occur only rarely in consort with numerous $\beta$-gal- progenitors. In mosaic mice, the borders between $\beta$-gal + and $\beta$-gal- patches are generally distinct, arguing against significant tangential migration that could otherwise account for only one $\beta$-gal + progenitor in a small area (Stone et al., 1995). Also, patch sizes in the lingual epithelium are relatively large, usually $\sim 50 \mu \mathrm{m}$, with patch sizes up to $1 \mathrm{~mm}$ not uncommon (Stone et al., 1995). Thus, the likelihood of a patch boundary coinciding with a taste bud is low; the likelihood of only a single lineage-marked cell falling within the progenitor pool is lower still. The relative incidence of taste buds with low numbers of $\beta$-gal-labeled cells suggests that, in some taste buds, progenitors contribute unequally. In support of this idea, we found occasional taste buds that contained one to two $\beta$-gal + cells (e.g., a palatal taste bud that appeared to contain only one $\beta$-gal + cell), a situation that would require the unlikely contribution of 25-55 progenitors if they all contributed equally. Taste buds with few labeled cells could occur if progenitors give rise to different numbers of progeny or if they take turns producing taste cells. For example, if four progenitors were to contribute to a taste bud and one of these divided at one-third the rate of the others, then it would give rise to only $10 \%$ of the final population. Taste cells with different lifespans also could result in a taste bud with few $\beta$-gal+ cells. Farbman $(1969,1980)$ reported that dark (type I) cells have a lifespan of $\sim 9 \mathrm{~d}$, whereas light (type II) cells live somewhat longer. Thus, the $\beta$-gal + cells in taste buds with the fewest positive cells may be dark cells if dark and light cell progenitors divide at the same rate and dark cells die more quickly. Alternatively, progenitors producing cells with longer lifespans may divide more slowly and contribute cells to the bud less often.

\section{5-HT-IR taste cell lineage analysis}

Our mosaic analysis of 5-HT-IR taste cells indicates that, within a taste bud, 5-HT-accumulating taste cells tend to be related by lineage, and, in individual taste buds, one or two progenitors give rise to this subpopulation. Several cell types exist in a taste bud, 
and controversy exists as to whether different cell types represent distinct lineages or whether one cell type grades into another as the taste cell matures (Delay et al., 1986). This controversy primarily centers around type I (dark), type II (light), and type III (intermediate) cells defined by ultrastructural characteristics. Cells that display 5-HT-IR belong to the type III class of taste cells (Takeda and Kitao, 1980; Uchida, 1985; Fujimoto et al., 1987; Kim and Roper, 1995; Yee et al., 2001), although not all type III cells exhibit 5-HT immunoreactivity (Yee et al., 2001). The cell lineage study presented here indicates that one class of type III cell, the 5-HT-IR cells, exhibit lineage relationships within the taste bud and therefore do not represent one stage of an age-related continuum of cells progressing from type I to type III to type II (dark to intermediate to light), as suggested previously.

The lineage relatedness among amine-accumulating type III cells suggests that at least some proliferative basal cells are restricted in terms of their ability to generate different taste cell types. Based on studies of other tissues, it is likely that more than one source of proliferating cells contributes to the taste bud cell population. In both the epidermis and the olfactory epithelium, two mitotically active basal cell populations exist [epidermis (Barrandon and Green, 1987; Potten and Morris, 1988) and olfactory epithelium (Graziadei and Metcalf, 1971; Graziadei and Monti Graziadei, 1978, 1979; Mackay-Sim and Kittel, 1991; Huard et al., 1998)]. One type of basal cell, the stem cell, has a long cell cycle and, by asymmetric division, maintains both a stem cell population and a second proliferative population. This second proliferative group of basal cells, like a transit-amplifying population, divides a limited number of times and then differentiates. This general scheme also has been proposed for intestinal epithelium (for review, see Gordon and Hermiston, 1994). Furthermore, studies of lingual epithelial basal cells indicate that more than one type of basal cell gives rise to the general lingual epithelium (Fukuda et al., 1978).

Two dividing populations may ultimately contribute to taste buds, with basal cells remote from the taste bud serving as the stem cell population and more proximate taste bud basal cells (and possibly perigemmal cells) serving as a lineage-restricted pool of transit-amplifying cells. The idea that both peripheral cells (perigemmal or surrounding cells) and basal cells within the taste bud contribute to the taste bud is consistent with reports of mitotic activity in both cell populations (Beidler and Smallman, 1965; Conger and Wells, 1969; Murray and Murray, 1971; Farbman, 1980; Delay et al., 1986). The lineage-restricted taste bud basal cells would likely include the mammalian achaete-scute homolog 1 (Mash1)-positive basal cells identified by Seta et al. (1999) and the BMP-4 (bone morphogenetic protein)-expressing basal cells identified by Yee and Finger (2001). Both of these markers are expressed by a specific subset of postmitotic taste cells, as well as the proliferative basal cells. This persistence of expression in only some types of taste cells may indicate that some basal cells only give rise to certain types of taste cells. Thus, for example, one population of basal cells might generate the neural-like type III cells, whereas a different set of basal cells gives rise to the more glial-like type I cells.

This lineage restriction could occur in one of two ways: either the original embryonic progenitor population is restricted or else the embryonic progenitors give rise to multipotent stem cells, which produce a lineage-restricted pool of proliferative basal cells (Fig. 5). In the first of these models, the original embryonic progenitor cells give rise to basal cells, which are restricted in

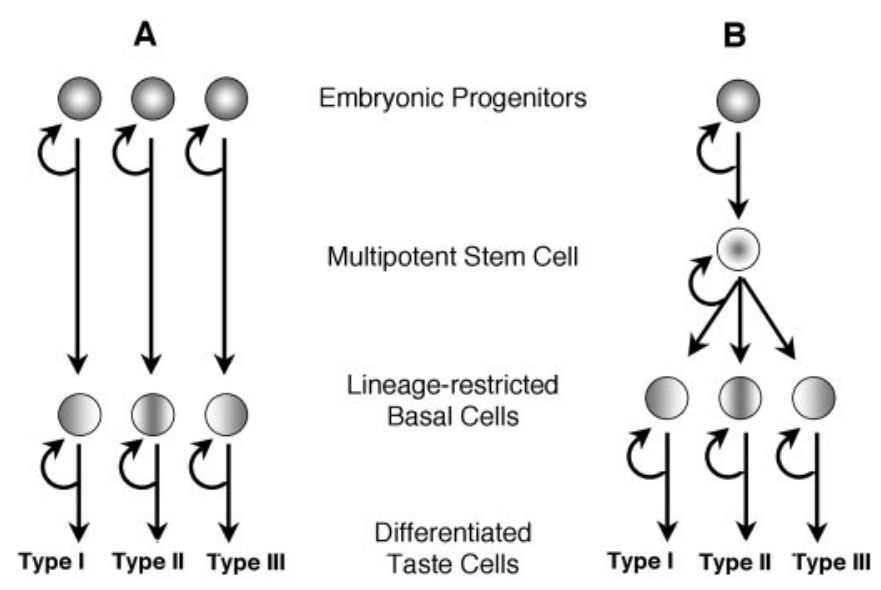

Figure 5. Schematic diagram showing possible lineage relationships in taste buds. $A$, In this scheme, the embryonic progenitor cells give rise to lineage-restricted basal cells that generate the different types of taste cells. $B$, In this scheme, the embryonic progenitors give rise to multipotent epithelial stem cells that generate lineage-restricted basal cells.

terms of their proliferative capabilities from the outset. Thus, a particular basal cell might generate only type III taste cells, whereas other basal cells would generate type II or type I taste cells (Fig. 5A). Conversely, the embryonic progenitors may give rise to multipotent stem cells, which continuously give rise to a set of lineage-restricted proliferative cells intimately associated with the taste buds. These gemmal proliferative cells then would give rise to the different types of taste cells (Fig. $5 B$ ). That is, proliferative cells near the taste bud (e.g., taste bud basal cells) may give rise to only one type of taste cell (type I, II, or III), whereas multipotent epithelial stem cells are capable of generating all types of epithelial cells, including the lineagerestricted gemmal proliferative cells. Our results are consonant with either model. Thus, additional study will be necessary to determine whether multipotent stem cells are present in association with adult taste buds.

\section{REFERENCES}

Barlow LA, Northcutt RG (1995) Embryonic origin of amphibian taste buds. Dev Biol 169:273-285.

Barrandon Y, Green H (1987) Cell migration is essential for sustained growth of keratinocyte colonies: the roles of transforming growth factor-alpha and epidermal growth factor. Cell 50:1131-1137.

Beidler LM, Smallman RL (1965) Renewal of cells within taste buds. J Cell Biol 27:263-272.

Conger AD, Wells MA (1969) Radiation and aging effect on taste structure and function. Radiat Res 37:31-49.

Delay RJ, Kinnamon JC, Roper SD (1986) Ultrastructure of mouse vallate taste buds. II. Cell types and cell lineage. J Comp Neurol 253:242-252.

Farbman AI (1965a) Fine structure of the taste bud. J Ultrastruct Res $12: 328-350$

Farbman AI (1965b) Electron microscope study of developing taste buds in rat fungiform papilla. Dev Biol 11:55-68.

Farbman AI (1969) Fine structure of degenerating taste buds after denervation. J Embryol Exp Morphol 22:55-68.

Farbman AI (1971) Development of the taste bud. In: Handbook of sensory physiology, Vol 4, Chemical senses II, Taste (Beidler L, ed), pp 51-61. Berlin: Springer.

Farbman AI (1980) Renewal of taste bud cells in rat circumvallate papillae. Cell Tissue Kinet 13:349-357.

Farbman AI, Mbiene JP (1991) Early development and innervation of taste bud-bearing papillae on the rat tongue. J Comp Neurol 304:172-186.

Farbman AI, Hellekant G, Nelson A (1985) Structure of taste buds in foliate papillae of the rhesus monkey Macaca mulatta. Am J Anat 172:41-56.

Finger TE, Simon SA (2000) Cell biology of taste epithelium. In: The 
neurobiology of taste and smell, Ed 2 (Finger TE, Silver WL, Restrepo D, eds), pp 287-314. New York: Wiley.

Fujimoto S, Murray RG (1970) Fine structure of degeneration and regeneration in denervated rabbit vallate taste buds. Anat Rec 168:393-413.

Fujimoto S, Ueda H, Kagawa H (1987) Immunocytochemistry on the localization of 5-hydroxytryptamine in monkey and rabbit taste buds. Acta Anat 128:80-83.

Fukuda M, Okamura K, Fujita S, Böhm N, Rohrbach R, Sandritter W (1978) The different stem cell populations in mouse epidermis and lingual epithelium. Pathol Res Pract 163:205-227.

Gautier C, Mehtali M, Lathe R (1989) A ubiquitous mammalian expression vector, $\mathrm{pHMG}$, based on a housekeeping gene promoter. Nucleic Acids Res 17:8389.

Goldstein JL, Brown MS (1990) Regulation of the mevalonate pathway. Nature 343:425-430.

Gordon JI, Hermiston ML (1994) Differentiation and self-renewal in the mouse gastrointestinal epithelium. Curr Opin Cell Biol 6:795-803.

Graziadei PPC, Metcalf JF (1971) Autoradiographic and ultrastructural observations on the frog's olfactory mucosa. Z Zellforsch Mikrosk Anat 116:305-318

Graziadei PPC, Monti Graziadei GA (1978) Continuous nerve cell renewal in the olfactory system. In: Handbook of sensory physiology, Vol IX, Development of sensory systems (Jacobson M, ed), pp 55-83. Berlin: Springer.

Graziadei PPC, Monti Graziadei GA (1979) Neurogenesis and neuron regeneration in the olfactory system of mammals. I. Morphological aspects of differentiation and structural organization of the olfactory sensory neurons. J Neurocytol 8:1-18.

Hall JM, Hooper JE, Finger TE (1999) Expression of sonic hedgehog, patched, and Gli1 in developing taste papillae of the mouse. J Comp Neurol 406:143-155.

Huard JM, Youngentob SL, Goldstein BJ, Luskin MB, Schwob JE (1998) Adult olfactory epithelium contains multipotent progenitors that give rise to neurons and non-neural cells. J Comp Neurol 400:469-486.

Kaufman MH (1992) The atlas of mouse development. London: Academic.

Kim D-J, Roper SD (1995) Localization of serotonin in taste buds: a comparative study in four vertebrates. J Comp Neurol 353:364-370.

Kinnamon JC, Taylor BJ, Delay RJ, Roper SD (1985) Ultrastructure of mouse vallate taste buds. I. Taste cells and their associated synapses. J Comp Neurol 235:48-60.

Lawton DM, Furness DN, Lindemann B, Hackney CM (2000) Localization of the glutamate-aspartate transporter, GLAST, in rat taste buds. Eur J Neurosci 12:3163-3171.

Lindemann B (1996) Taste reception. Physiol Rev 76:719-766.
Lyon MF (1961) Gene action in the X-chromosome of the mouse (Mus musculus). Nature 190:372-373.

Mackay-Sim A, Kittel P (1991) Cell dynamics in the adult mouse olfactory epithelium: a quantitative autoradiographic study. J Neurosci 11:979-984.

Murray RG (1969) Cell types in rabbit taste buds. In: Olfaction and taste III (Pfaffman C, ed), pp 331-334. New York: Rockefeller UP.

Murray RG (1973) The ultrastructure of taste buds. In: The ultrastructure of sensory organs (Friedmann I, ed), pp 1-81. New York: Elsevier.

Murray RG (1986) The mammalian taste bud type III cell: a critical analysis. J Ultrastruct Mol Struct Res 95:175-188.

Murray RG, Murray A (1971) Relations and possible significance of taste bud cells. Contrib Sens Physiol 5:47-95.

Paulson RB, Hayes TG, Sucheston ME (1985) Scanning electron microscope study of tongue development in the CD-1 mouse fetus. J Craniofac Genet Dev Biol 5:59-73.

Potten CS, Morris RJ (1988) Epithelial stem cells in vivo. J Cell Sci [Suppl] 10:45-62.

Pumplin DW, Yu C, Smith DV (1997) Light and dark cells of rat vallate taste buds are morphologically distinct cell types. J Comp Neurol 378:389-410

Seta Y, Toyono T, Takeda S, Toyoshima K (1999) Expression of Mash1 in basal cells of rat circumvallate taste buds is dependent upon gustatory innervation. FEBS Lett 444:43-46.

Stone LM, Finger TE, Tam PPL, Tan S-S (1995) Taste receptor cells arise from local epithelium, not neurogenic ectoderm. Proc Natl Acad Sci USA 92:1916-1920.

Takeda M (1977) Uptake of 5-hydroxytryptophan by gustatory cells in the mouse taste bud. Arch Histol Jpn 40:243-250.

Takeda M, Kitao K (1980) Effect of monoamines on the taste buds in the mouse. Cell Tissue Res 210:71-78.

Takeda M, Shishido Y, Kitao K, Suzuki Y (1981) Biogenic monoamines in developing taste buds of mouse circumvallate papillae. Arch Histol Jpn 44:485-495.

Tam PPL, Tan S-S (1992) The somitogenetic potential of cells in the primitive streak and the tail bud of the organogenesis-stage mouse embryos. Development 115:703-715.

Tan S-S, Williams EA, Tam PPL (1993) X-chromosome inactivation occurs at different times in different tissues of the post-implantation mouse embryo. Nat Genet 3:170-174.

Uchida T (1985) Serotonin-like immunoreactivity in the taste bud of the mouse circumvallate papilla. Jpn J Oral Biol 27:132-139.

Yee C, Finger TE (2001) Bone morphogenetic protein 4 (BMP-4) is present in taste cells of adult mice. Chem Senses 26:1123.

Yee C, Yang R, Böttger B, Finger TE, Kinnamon JC (2001) "Type III" cells of rat taste buds: immunohistochemical and ultrastructural studies of neuron specific enolase, protein gene product 9.5 and serotonin. J Comp Neurol 440:97-108. 